\title{
Pengembangan Media Pembelajaran dengan Video Based Learning di Akademi Kebidanan Pelamonia
}

\author{
Basuki Rahmat $^{1]}$, Darmiati ${ }^{2]}$ \\ Institut Ilmu Kesehatan Pelamonia Kesdam XIV/Hasanuddin \\ E-Mail: ${ }^{1]}$ deoukiore@gmail.com \\ ${ }^{2]}$ darmiati@akbidpelamonia.ac.id
}

\begin{abstract}
Abstrak
Video Based Learning atau pembelajaran berbasis video adalah salah satu metode yang telah menjadi tren dalam e-learning dekade ini. Akademi Kebidanan Pelamonia saat ini menjadi Center of excellent pendidikan kebidanan Indonesia, prestasi tersebut adalah sebuah hasil dari kinerja seluruh sivitas akademika Akbid Pelamonia. Mata kuliah kegawatdaruratan yang dikemas dengan porsi 6 sks menjadi tantangan tersendiri bagi dosen pengampu mata kuliah. Selain karena porsi jam yang sangat banyak, kemampuan dosen dalam menyajikan materi juga menjadi pertimbangan agar efektif dan efisien dalam penyajiaannya. Sehingga peneliti tertarik untuk membuat media pembejaran dengan Video Based Learning pada mata kuliah kegawatdaruratan. Penelitian ini bertujuan untuk menghasilkan produk berupa media pembelajaran berbasis video Persalinan Letak Sungsang pada mata kuliah kegawatdaruratan. Penelitian ini merupakan penelitian pengembangan dengan enam tahap, yaitu: potensi masalah, pengumpulan data, design produk, validasi desain, revisi dan uji coba produk. Berdasarkan hasil pengembangan media dan pengujian terhadap media pembelajaran dengan Video Based Learning pada mata kuliah Kegawatdaruratan Maternal Neonatal dikatakan berhasil setelah diriview oleh ahli materi dengan hasil sangat baik dan pembelajaran baik. Adapun penilaian oleh ahli media dengan hasil tanmpilan baik dan pemrograman sangat baik. Selanjutnya pada pengujian pada mahasiswa melalui dua kelompok yaitu kelompok kecil dengan rata-rata memperoleh nilai persentase $92 \%$ denga kriteria "sangat menarik", seperti halnya pada saat pengujian di kelompok besar dengan nilai persentase $90 \%$ dengan kriteria "sangat menarik" sehingga kesimpulan dari penelitian ini adalah media video yang dikembangkan "sangat layak" untuk digunakan.
\end{abstract}

Kata Kunci: Teknologi, Media Pembelajaran, Video Based Learning, Kegawatdaruratan

\section{Learning Media Development with Video Based Learning at the Pelamonia Midwifery Academy}

\begin{abstract}
Video Based Learning or video-based learning is one method that has become a trend in e-learning this decade. The Pelamonia Midwifery Academy is currently the Center of excellence for Indonesian midwifery education, this achievement is a result of the performance of the entire academic community of the Pelamonia Academy. Emergency
\end{abstract}


courses that are packaged with a portion of 6 credits are a challenge for lecturers who support courses. In addition to the very large portion of hours, the ability of lecturers in presenting the material is also a consideration so that it is effective and efficient in its presentation. So that researchers are interested in making learning media with Video Based Learning in emergency courses. This study aims to produce a product in the form of video-based learning media for breech delivery in emergency courses. This research is a development research with six stages, namely: potential problems, data collection, product design, design validation, revision and product testing. Based on the results of media development and testing of learning media with Video Based Learning in the Maternal Neonatal Emergency course, it is said to be successful after being reviewed by material experts with very good results and good learning. As for the assessment by media experts with good display results and very good programming. Furthermore, in testing on students through two groups, namely a small group with an average score of 92\% with the criteria of "very interesting", as well as when testing in large groups with a percentage value of $90 \%$ with the criteria of "very interesting" so that the conclusions of the study this is a video medium developed "very feasible" to use.

Keywords: Technology, Instructional Media, Video Based Learning, Emergency

\section{PENDAHULUAN}

Secara sederhana, pendidikan dapat dipahami sebagai upaya manusia dalam membentuk diri pribadinya sesuai dengan tatanan nilai yang berkembang di dalam masyarakat baik secara budaya maupun agama. Pendidikan yang dimaksud adalah bentuk dari perwujudan budaya yang dinamis dalam menerima perkembangan. Perkembangan dan perubahan pada sisi pendidikan baik nilai maupun matode adalah sesuatu yang sulit dibendung perubahannya, maeskpin demikian perkembangan dan perubahan ini diharapkan tetp sejalan dengan perubahan budaya dalam siklus kehidupan manusia dari masa ke masa. Perubahan yang dimaksud adalah perubahan dalam arti perbaikan untuk mengantisipasi pesatnya berubahan dalam banyak kepentingan di masa yang akan datang.

Dalam lingkungan perguruan tinggi otonomi terhadap kurikulum adalah peluang bagi perguruan tinggi untuk berkreasi dalam mencapai tujuannya lebih cepat dalam hal proses pembelajaran dan kompetensi peserta didiknya. Tentu hal ini menuntut kemampuan dan kecermatan dosen dalam memilih dan menentukan komponen yang diperlukan dalam proses pembelajaran. Komponen yang dimaksud diantaranya kesiapan peserta didik, kesiapan dosen sendiri, ketersediaan media pembelajaran, kurikulum serta fasilitas penunjang pembelajaran.

Berdasarkan komponen pembelajaran yang dijelaskan sebelumnya, media ajar adalah salah satu komponen yang memiliki pengaruh cukup besar dalam proses pembelajaran, hal ini karena interaksi mahasiswa dengan media tersebut terwujud nyata dari tindak belajar, melihat keadaan belajar mahasiswa ketika sedang berinteraksi dengan media yang digunakan. Dengan demikian pembelajaran akan sulit dilakukan jika tidak ada bahan ajar yang disajikan melaui media yang dipilih.

Perkembangan terknologi kian sulit dihindari, hari-hari dimana para mahasiswa menggunakan buku teks dan 
buku tulis perlahan hilang. Saat ini, banyak metode belajar yang berkembang, tentunya efektif dan menarik sehingga mahasiswa tersebut dapat memperoleh lebih banyak pengetahuan dengan waktu yang singkat. Video Based Learning atau pembelajaran berbasis video adalah salah satu metode yang telah menjadi trend dalam e-learning dekade ini.

Pada proses belajar, perubahan perilaku yang terjadi tergantung pada kemapuan mahasiswa untuk belajar terus menerus, bukan hanya dari proses tumbuhnya di lingkungan sekitar. Jika dilihat secara mendalam faktor yang mempengaruhi hasil belajar tidak terlepas dari skill, pengatahuan, perilaku dan nalai. Sehingga hasil belajar harus dislihat dari sisi stimulus dan proses kognitifnya.

Pengembangan dari media pembelajaran adalah salah satu bentuk upaya peningkatan mutu yang tertuju pada proses perancangan medianya. Sebab media akan disusun berdasarkan materi yang akan disampaikan. Adapun Manfaat Pembelajaran Berbasis Video telah memikat dunia pendidikan sejak penciptaannya. Karena otak manusia terhubung untuk melacak gerakan dan tertarik pada gerakan, video dapat membuat sesuatu menjadi lebih menarik daripada sekedar teks. Salah satu contoh, sebuah animasi dapat menjelaskan sebuah konsep, betapapun sulitnya konsep itu akan membuat anakanak dan orang dewasa duduk diam untuk menonton.

Pemilihan media video ini tidak terlepas dari data Kemenkominfo Republik Indonesia yang merilis bahwa saat ini internet tidak hanya digunakan untuk hiburan, belanja atau media sosial tetapi juga dipergunakan untuk edukasi (Astrid, 2016). Yang menarik adalah konten video menjadi konten yang paling banyak di ikuti, bahkan platform youtube yang berbasis video diikuti lebih dari 2 miliar member. Youtube sendiri merupakan sistus video sharing yang bisa menjadi ruang untuk bertukar informasi. Perkembangan ini harus menjadi peluang dalam menentukan media yang relevan digunakan dalam masa sekarang.

Pembaharuan dalam penggunaan media dalam proses pembelajaran adalah upaya untuk mengikuti perkembangan tekhnologi yang kian pesat, selain upaya penyesuaian pada proses juga sebagai jawaban bahwa institusi mampu menyesuaikan diri terhadap perubahan-perubahan yang terjadi. Respon ini menjadi terobosan untuk mewujudkan transfer pengetahuan yang diarahkan pada kemajuan.

Akademi Kebidanan Pelamonia sejak berdiri pada tahun 2008 sampai saat ini cukup konsisten dalam menghasilkan lulusan yang siap guna dan tepat guna ditengah masayarakat, hal itu dibuktikan dengan terpilihnya AKBID Pelamonia sebagai Center of excellent pendidikan kebidanan Indonesia, hal ini adalah angin segar untuk seluruh elemen yang ada, prestasi tersebut juga adalah sebuah hasil dari kinerja seluruh sivitas akademika Akbid Pelamonia. Dari sisi yang berbeda prestasi ini menjadi cambuk awal untuk seluruh elemen didalam organisasi untuk mengembangkan diri, termasuk kemapuan dosen dalam mengembangkan metode pembelajaran berbasis teknologi yang perkembangannya kian waktu kian pesat.

Kehadiran media pembelajaran
sangat dibutuhkan dalam masa
sekarang, selain untuk lebih
memudahkan mahasiswa dalam
menyerap ilmu pengetahuan, konsep
videonya real time juga bisa diulang-
ulang tanpa batas waktu, sehingga bisa


digunakan dan dilihat kapan saja. Keunggulan dari pemanfaatan video pembelajaran, bisa digunakan secara mandiri oleh mahasiswa dalam memperdalam isi materi yang disajikan. Beragamnya ilustrasi yang disajikan menjadi salah satu hal yang manarik untuk menstimulus mahasiswa dalam memahami materi.

Program studi DIII Kebidanan merupakan pendidikan kesehatan yang bertujuan menghasilkan tenaga kesehatan yang memiliki kompetensi dalam bidang kebidanan. Dalam pembangunan dibidang kesehatan, program studi kebidanan memiliki tanggung jawab yang cukup kompleks dalam mempersiapkan luaran tenaga kesehatan yang handal dan memiliki kompetensi yang terstandar. Untuk mewujudkan nawa cita tersebut Akbid Pelamonia telah menjalankan fungsinya telah melakukan banyak terobosan baik dari segi pengembangan SDM, Kurikulum, serta menciptakan iklim yang kondusif bagi terlaksananya proses belajar mengajar.

Dalam pencapaian visi, proses pembelajaran menjadi satu faktor yang cukup vital. Suasana belajar, kemampuan serta komitmen dosen juga tidak kalah penting, sebab dosen adalah ujung tombak dalam proses transfer pengetahuan ke peserta didik. Keterampilan mahasiswa akan semakin meningkat berbanding lurus dengan kemampuan dosen dalam menyajikan materi. Strategi pembelajaran dengan metode ceramah, simulasi maupun diskusi $40 \%$ telah dilakukan di kelas dalam bentuk materi teori dan $60 \%$ praktik dilaksanakan di laboratorium.

Kurikulum yang telah disusun dengan baik, tentunya merumuskan tujuan yang harus tercapai secara maksimal untuk menghasilkan luaran atau lulusan yang kompeten (Marwijah, dkk, 2014). Penggunaan video pembelajaran dalam praktik Persalinan Letak Sungsang menjadi salah satu penunjang dalam mata kuliah kegawatdaruratan maternal dan neonatal. Media ini diharapkan mampu mengubah pola belajar mahasiswa untuk aktif dalam proses pembelajaran serta diharapkan mampu menjadi stimulus untuk meningkatkan motivasi dan minat belajar mahasiswa, meskipun penggunaan media apapun tidak bisa menggantikan peranan dosen (Mulyana dan Solatun, 2013). Pembelajaran berbasis video menurut (Noveri, 2020), karakteristik media dapat dilihat dari kemampuan membangkitkan rangsangan indra penglihatan, pendengaran, perabaan atau kesesuainnya dengan tingkat hirarki belajar melibatkan hampir seluruh unsur indera manusia, sehingga penggunaan media video dapat memudahkan mahasiswa dalam memahami materi yang disajikan.

Penelitian pengembangan media pembelajaran berbasis video yang telah dilakukan sebelumnya, (Hasthagina dan Hellen, 2013) dengan judul Pengembangan Media Video Pembelajaran Penatalaksanaan Atonia Uteri Jurusan Kebidanan di Politeknik Kesehatan. Dengan hasil validasi dari ahli media penyebutkan bahwa media pembelajaran yang dibuat $97.5 \%$ dalam kriteria valid atau dapat disimpulkan dengan kata layak digunakan untuk proses pembelajaran. Adapun (Kristanto, 2011) mengambil judul Pengembangan Model Media Video Pembelajaran Mata Kuliah Pengembangan Media Video/TV Program Studi Teknologi Pendidikan Fakultas Ilmu Pendidikan Universitas Negeri Surabaya dengan kesimpulan bahwa penggunaan media video pembelajaran dalam uji coba lapangan mampu meningkatkan pemahaman materi dan sudah memenuhi kategori "sangat baik" dan layak digunakan 
dalam pembelajaran. (Marwijah, dkk, 2014) melakukan penelitian Pengembangan Video Pembelajaran Praktik Pemberian Nutrisi melalui NGT mata Kuliah Keterampilan Dsar Kebidanan di DIII Kebidanan dengan hasil penelitian menyimpulkan video pembelajaran NGT yang dikembangakan sangsat praktis dalam penggunaannya, setelah dilakukan uji coba kepada mahasiswa baik dengan metode one to one maumpun small group terlihat pada peningkatan nilai mahasiswa dengan rata-rata 89.81 dengan aktegori sangat baik dan tuntas $100 \%$.

Hasil observasi dan analisis terhadap beberapa peneliti terdahulu, terlihat kesamaan bentuk penelitian melalui pengembangan media pembelajaran berbasis video, sehingga dalam penelitian ini peneliti akan mengembangkan media pembelajaran yang juga berbasis video pada mata kuliah kewatdaruratan dimana mata kuliah ini di DIII Kebidanan Pelamonia dikemas dengan porsi 6 sks, sehingga akan menjadi tantangan tersendiri bagi dosen pengampu mata kuliah. Selain karena porsi jam yang sangat banyak, kemampuan dosen dalam menyajikan materi juga menjadi pertimbangan agar efektif dan efisien dalam penyajiaannya. Sehingga peneliti tertarik untuk membuat media pembejaran dengan Video Based Learning pada mata kuliah kegawatdaruratan.

\section{METODE}

Desain

pengembangan berbasis video tujuannya untuk menghasilkan perangkat yang nantinya menunjang kegiatan pembelajaran pada mata kuliah kegawatdaruratan di Prodi D III Kebidanan Pelamonia. Metode penelitian yang digunakan dalam penelitian ini adalah metode penelitian dan pengembangan (research and Development), yaitu suatau proses yang digunakan untuk mengembangkan dan memvalidasi produk penelitian. Hasil produk kemudian diuji tingkat efektifitas dari produk tersebut (Sugiyono, 2014).

Penelitian ini memiliki langkahlangkah penelitian dan pengembangan meliputi penelitian pendahuluan, pengembangan produk video sampai pada proses uji. Metode yang seharusnya terdiri dari 10 tahap, dibuat hanya sampai pada tahap ke enam 6 disebabkan karena adanya beberapa revisi untuk bentuk penelitian dengan skala produk yang kecil.

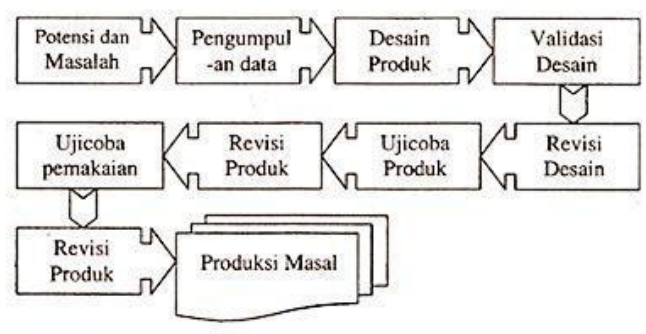

\section{Gambar 1. Langkah pengembangan media pembelajaran}

Proses tersebut diharapkan menghasilkan produk yang telah disempurnakan. Dan tahap akhirnya ada proses pengujian untuk melihat sejauh mana efektifitas produk yang dibuat. Terutama untuk menjawab tujuan pembelajaran yang diharapkan oleh peneliti dan juga dosen pengampu mata kuliah.

Rancangan kegiatan penelitian pengembangan ini sebagaimana yang terdapat pada gambar 1 hanya sampai pada uji coba produk Video pembelajaran pertolongan persalinan letak sungsang pada mata kuliah Kegawatdaruratan Maternal dan Neonatal. Dengan demikian, gambaran penelitian yang akan dilakukan akan 
peneliti bagi menjadi tiga sub kegiatan yang mencakup studi pendahuluan, pengembangan media dan evaluasi. Untuk lebih spesifik ada digambar berikut:

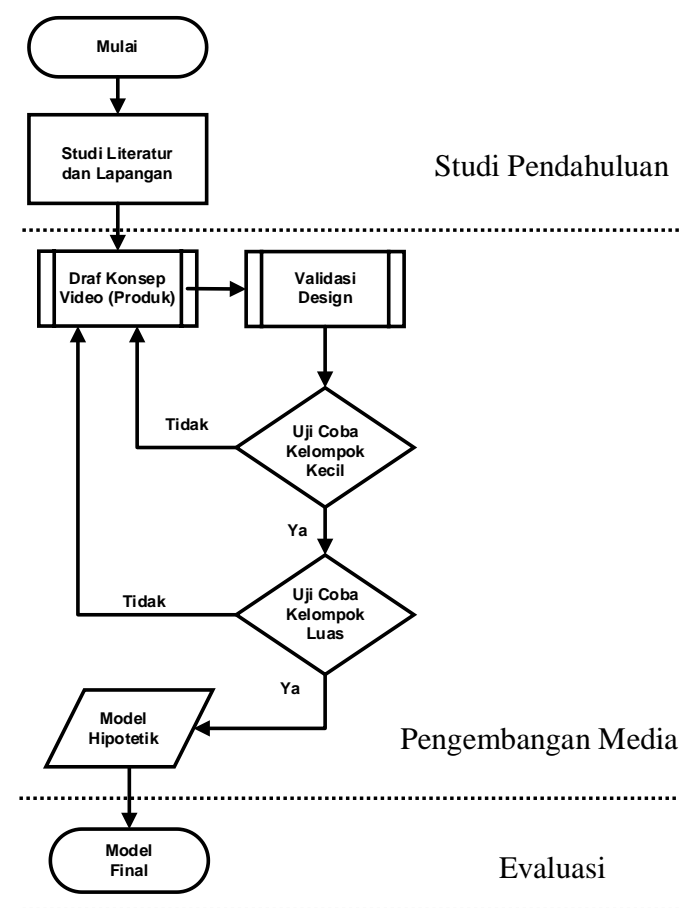

Gambar 2. Alur pengembangan media

\section{a. Studi Pendahuluan}

Studi pendahuluan merupakan tahap awal dalam melakukan penelitian dan pengembangan model. Pada proses ini, peneliti melakukan observasi sertsa mengumpulkan data-data yang diperlukan dalam kegiatan penelitian.

Data yang perlu digali adalah data tentang masalah yang menjadi dasar pembuatan media pembelajaran, serta format materi yang dibutuhkan dalam mengembangkan media pembelajaran. Kegiatan ini meliputi analisis kebutuhan, pengumpulan tinjauan pustaka, observasi langsung di tempat penelitian dan mengidentifikasi masalah yang ditemukan. Adapun dalam menganalisis kebutuhan ada beberapa rambu yang harus menjadi acuan, yang pertama adalah apakah produk yang dikembangankan dalam penelitian benar-banar akan memiliki manfaat khususnya dalam bidang pendidikan. Yang kedua apakah produk tersebut bisa atau memungkinkan untuk dikembangan. Ketiga apakah ada sumber daya manusia memeliki pengalaman, pengetahuan atau keterampilan dalam pengembangan produk tersebut. Keempat apakah ada waktu dan kesempatan untuk mengembangkan produk tersebut.

Pertanyaan-pertanya itu harus dijawab agar produk tersebut bisa dikembangan. Setelah semua pertanyaan bisa dijawab dan jawabannyanya positif maka kegiatan selanjutnya adalah pengembangan media.

\section{b. Pengembangan Media}

Setelah kegiatan studi pendahuluan, pada tahap ini dilakukan pembuatan produk media pembelajaran. Dimulai dari membuat draf konsep video yang akan diproduksi kemudian desainnya divalidasi melalui kelompok kecil dan kelompok besar.

Pada kegiatan ini dilakukan perencanaan untuk menentukan alat dan bahan yang akan digunakan. Setelah semua bahan telah ditentukan maka langkah selanjutnya adalah mulai membuat produk.

Seperti pada pengembanganpengembagan produk yang lain, pengembangan ini juga membutuhkan uji validasi dari beberapa ahli. Dalam penelitian ini melibatkan 2 ahli yaitu ahli materi dan ahli media. Pada tahapan ini ada kemungkinan produk akan derevisi berulang jika belum memenuhi standar dari hasil penilaian para ahli.

Setelah sudah lolos uji validasi maka produk akan di uji coba melalui kelompok kecil dan kelompok besar 
untuk melihat kelayakan media yang dibangun dalam penelitian.

Jika seluruh pengujian berhasil dilakukan dan diterima maka masuk pada tahap produksi.

\section{c. Evaluasi}

Evaluasi adalah kegiatan akhir dari produksi produk yang selanjutnya di nilai oleh ahli materi dan ahli media.

Adapun Instrumen penelitian yang digunaakn dimana instrumen ini naninya menjadi suatu alat yang digunakan untuk melihat atau mengukur fenomena yang sedang diamati.

Penilaian media berbasis video diberikan kepada dua ahli yaitu ahli media dan ahli materi sebagai bentuk pengujian terhadap media yang dikembangakan. Kelayakan media pembelajaran berbasis video digunakan alat ukur skala likert, adapun variabel yang akan di ukur dijabarkan dalam indikator variabel. Indikator variabel yang telah ditentukan akan dijadikan sebagai dasar dalam penyusunan item instrumen yang dikembangkan dalam bentuk pertanyaan atau pernyataan. Sehingga jawaban setiap item instrumen yang menggunakan skala likert diharapkan mempunyai gradasi dari penilaian sangat positif sampai sangat negatif.

Skala likert menurut pendapat (Sugiyono, 2014) akan dijelaskan dalam gambaran tabel 1 dan 2 berikut:

Tabel 1. Kriteria penilaian kelayakan

\begin{tabular}{lc}
\hline Kategori Penilaian & P $(\boldsymbol{\%})$ \\
\hline Sangat Layak & $85-100$ \\
Layak & $75-84$ \\
Cukup & $60-74$ \\
Kurang & $45-59$ \\
Sangat Kurang & $0-44$ \\
\hline
\end{tabular}

Tabel 2. Interpretasi kriteria hasil penelitian

\begin{tabular}{|c|c|}
\hline Kategori Penilaian & Interpretasi \\
\hline Sangat Layak & $\begin{array}{l}\text { Ahli materi dan ahli media } \\
\text { menyatakan bahwa media } \\
\text { pembelajaran berbasis video } \\
\text { sangat baik untuk digunakan } \\
\text { sebagai media pembelajaran } \\
\text { dan tidak perlu direvisi }\end{array}$ \\
\hline Baik & $\begin{array}{l}\text { Ahli materi dan ahli media } \\
\text { menyatakan bahwa media } \\
\text { pembelajaran berbasis video } \\
\text { baik untuk digunakan sebagai } \\
\text { media pembelajaran dan tidak } \\
\text { perlu direvisi }\end{array}$ \\
\hline Cukup & $\begin{array}{l}\text { Ahli materi dan ahli media } \\
\text { menyatakan bahwa media } \\
\text { pembelajaran berbasis video } \\
\text { cukup untuk digunakan sebagai } \\
\text { media pembelajaran dan perlu } \\
\text { direvisi }\end{array}$ \\
\hline Kurang & $\begin{array}{l}\text { Ahli materi dan ahli media } \\
\text { menyatakan bahwa media } \\
\text { pembelajaran berbasis video } \\
\text { kurang untuk digunakan } \\
\text { sebagai media pembelajaran } \\
\text { dan perlu direvisi }\end{array}$ \\
\hline Sangat Kurang & $\begin{array}{l}\text { Ahli materi dan ahli media } \\
\text { menyatakan bahwa media } \\
\text { pembelajaran berbasis video } \\
\text { sangat kurang untuk digunakan } \\
\text { sebagai media pembelajaran } \\
\text { dan perlu direvisi secara total }\end{array}$ \\
\hline
\end{tabular}

Data yang diperoleh dari penelitian ini adalah data kualitatif dan data kuantitatif. Data kualitatif berupa kritik dan saran dari ahli media dan ahli materi, sedangkan untuk data kuantitatif berupa daya kelayakan media. Untuk menganalisis kualitas materi, kelayakan media pembelajaran, tampilan video dan pemrograman akan dilakukakan langkah sebagai berikut:

- Melakukan tabulasi/rekapitulasi data hasil penelitian

- Menghitung rata-rata skor tiap indikator dengan rumus:

$$
\begin{aligned}
& \multicolumn{1}{c}{\mathrm{P}=\frac{\sum x}{\sum x 1} \times 100} \\
& \mathrm{P} \quad=\text { Kelayakan } \\
& \sum X \quad=\text { Jumlah jawaban pilihan } \\
& \sum X 1=\text { Jumlah jawaban tertinggi }
\end{aligned}
$$


3. HASIL DAN PEMBAHASAN

Analisis data yang telah dilakukan adalah proses pemecahan masalah atau permasalahan awal yang telah diketahui sebagai langkah agar tujuan penelitian dapat tercapai dan hipotesis bisa terjawab dengan baik. Oleh sebab itu pendekatan penelitian yang digunakan harus disesuaikan dengan masalah yang akan diteliti atau dibuat. Kegiatan penelitian yang telah dilaksanakan terbagi dalam tiga sub kegiatan utama sebagai berikut:

\section{a. Tahap Studi Pendahuluan}

Pada tahap ini terdapat dua tahapan kegiatan yang menjadi fokus utama yaitu studi literatur dan studi lapangan. Studi literatur adalah kegiatan mencari referensi ataupun pustaka untuk memperkuat teori penunjang dari tema penelitian tentang pengembangan media pembelajaran berbasis video. Sedangkan studi lapangan melakukan observasi langsung kepada dosen dan mahasiswa untuk menggali informasi, permasalah serta mengidentifikasi masalah yang ada.

$$
\text { Pada studi pendahuluan }
$$
ditemukan masalah yang cukup kompleks yaitu dosen mengalami kesulitan dalam melakukan proses pembelajaran praktikum dengan konsep pembelajaran jarak jauh. Masalah tersebut mucul karena lemahnya inisiatif diri dari mahasiswa untuk mengikuti pembelajaran jarak jauh, masalah lain adalah jaringan yang kurang stabil karena lokasi tempat mahasiswa berbeda-beda sehingga kualitas jaringan yang mereka gunakan.
Setelah menemukan dan mencatat informasi awal mengenai masalah-masalah didalam kelas, maka peneliti merancang sebuah media pembelajaran yang dianggap bisa menjadi solusi dalam membantu proses transfer pengetahuan dari dosen kepada mahasiswa secara efektif dan efisien.

Media yang akan dibangun tentunya harus menarik agar nantinya akan meningkatkan animo mahasiswa dalam mengikuti setiap tahapan materinya. Materi yang disajikan juga diupayakan ringkas tetapi lebih mudah dipahami oleh mahasiswa.

\section{b. Tahap Pengembangan Media}

Pada tahap pengembangan media terdapat tiga sub pokok kegiatan yang telah dilaksanakan, yaitu:

\section{1). Penyusunan draft materi dan konsep video}

Data yang telah didapatkan dari proses studi pustaka dan studi lapangan menjadi dasar peneliti dalam menetukan draft materi dan konsep video pembelajaran yang akan dikembangkan. Adapun langkah-langkah yang telah disusun adalah: (1) penyusunan draft materi dalam bentuk daftar tilik, naskah, storyboard video pembelajaran yang tetap mengacu pada modul pembelajaran mata kuliah kegawatdaruratan maternal dan neonatal. (2) Proses pengambilan footage video di laboratorium mini hospital prodi D-III Kebidanan Institut Ilmu Kesehatan Pelamonia. (3) proses editing video menggunakan perangkat keras berupa PC dengan software Adobe 
Premiere Pro 2020. Pada tahap ini output yang dihasilkan adalah media pembelajaran dalam bentuk video dengan ekstensi .*mp4 dengan tema besar adalah "Persalinan Letak Sungsang" pada mata kuliah kegawatdaruratan maternal dan neonatal. Materi yang disajikan berupa pengenalan setiap alat yang akan digunakan serta penjelasan dari setiap aktifitas kompetensi yang diperagakan oleh model.

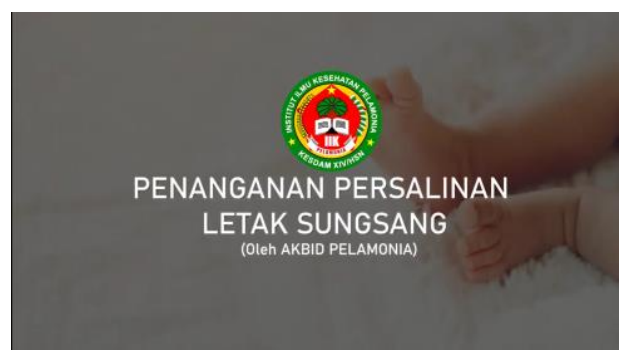

Gambar 3. Pembuka video

Tampilan halaman dibuat sederhana dengan hanya memunculkan judul besar dari materi yang akan disajikan yaitu "PENANGANAN PERSALINAN LETAK SUNGSANG”.

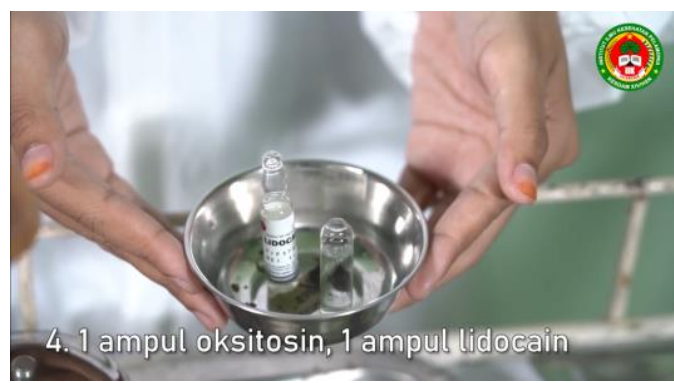

Gambar 4. Pengenalan alat \& bahan

Di awal video disajikan pengenalan setiap alat yang akan umumnya digunakan dalam persalinan, khusunya pertolongan persalinan letak sungsang, alat dijelaskan dengan cara menunjukkan alatnya kemudian ada narasi dan narator yang menjelaskan tentang alat yang terlihat di layar.

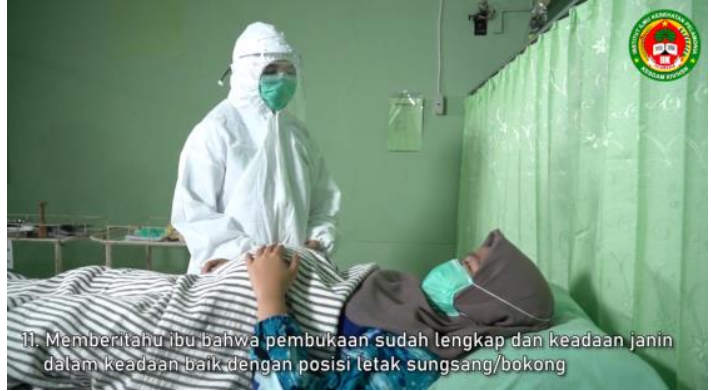

Gambar 5. Simulasi langsung dengan pasien

Setelah pengenalan alat yang akan digunakan, tahapan selanjutnya adalah memperlihatkan bagaimana seharusnya bidan berkomunikasi lebih banyak pada pasien yang akan ditangani, tentu dengan etika-etika kebidanan yang telah dipelajari pada mata kuliah yang lain.

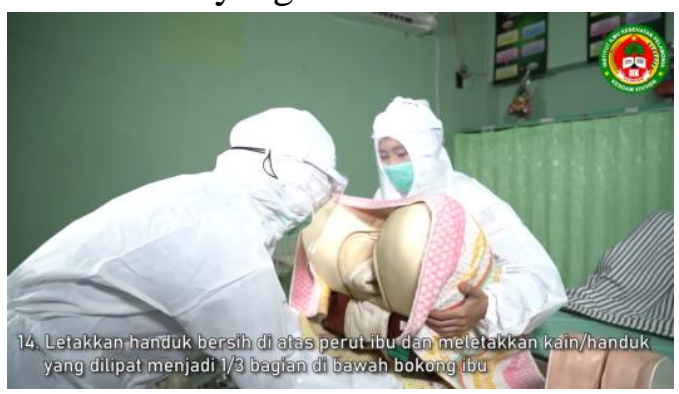

Gambar 6. Penanganan menggunakan Pantom

Penanganan pasien dalam video pembelajaran masih penggunakan phantom untuk menghindari hal-hal yang tidak memungkinkan untuk tampil dalam video terkait privasi dan hal-hal yang tidak pantas ditunjukkan.

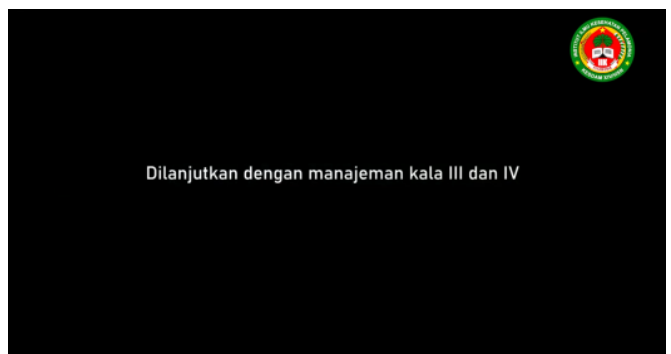

Gambar 7. Penutup (penanganan selanjutnya) 
Pada penutup video dijelaskan tentang penanganan-penanganan selanjutnya setelah pertolongan persalinan letak sungsang yang akan dilakakukan.

\section{2). Validasi Tim Ahli (Materi dan Media)}

Validitas penilaian
penilitian ini mengacu
pendapata
menyatakan bahwa instrumen yang valid harus diukur dengan alat ukur yang juga valid. Valid adalah instrumen tersebut dapat digunakan untuk mengukur apa yang seharusnya diukur.

Penilaian terhadap materi dilakukan oleh dosen pengampu mata kuliah kagawatdaruratan maternal dan noenatal. Penilaian yang dilakukan ditinjau dari aspek materi dan aspek pembelajaran. Hasil penilaian ahli materi sebagai berikut:

Tabel 3. Penilaian kualitas materi praktik

\begin{tabular}{|c|c|}
\hline $\begin{array}{l}\text { Aspek } \\
\text { Penilaian }\end{array}$ & Aspek yang Dinilai \\
\hline 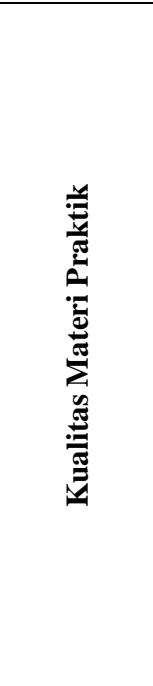 & $\begin{array}{l}\text { Materi yang dipilih sesuai dengan } \\
\text { materi Kegawatdaruratan } \\
\text { Materi yang disajikan sudah lengkap } \\
\text { untuk materi Persalinan letak } \\
\text { sungsang pada mata kuliah } \\
\text { kegawatdaruratan } \\
\text { Materi yang disampaikan sudah } \\
\text { mengikuti perkembangan } \\
\text { pengetahuan yang terbaru } \\
\text { Tahapan-tahap didalam video tutorial } \\
\text { sudah tepat } \\
\text { Pertolongan pada persalinan letak } \\
\text { sungsang tersampaikan dengan baik } \\
\text { dalam video } \\
\text { Jumlah langkah dan tahapan sudah } \\
\text { benar dan tepat model yang menolong } \\
\text { Gerakan mon benar } \\
\text { persalinan dalam video sudah benan } \\
\text { dan tepat }\end{array}$ \\
\hline
\end{tabular}

Tabel 4. Penilaian kualitas materi pembelajaran

\begin{tabular}{|c|c|}
\hline $\begin{array}{l}\text { Aspek } \\
\text { Penilaian }\end{array}$ & Aspek yang Dinilai \\
\hline 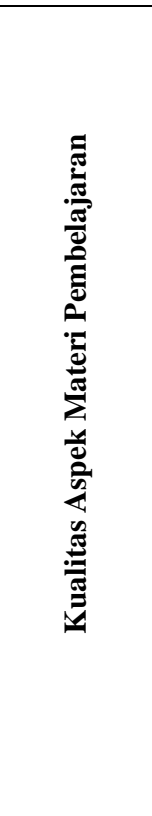 & $\begin{array}{l}\text { Video tutorial mampu merangsang } \\
\text { mahasiswa untuk mengikuti setiap } \\
\text { tahapan dalam menolong persalinan } \\
\text { letak sungsang } \\
\text { Mendorong motivasi mahasiswa } \\
\text { dalam menghapal setiap langkah yang } \\
\text { harus ditempuh dalam menolong } \\
\text { persalinan letak sungsang } \\
\text { Setiap langkah dan tahapan didalam } \\
\text { video mudah dipahami } \\
\text { Penjelasan tahapan dan langkah } \\
\text { dalam video pembelajaran sangat } \\
\text { lengkap map dilengkapi } \\
\text { Memudahkan mahasiswa memahami } \\
\text { materi karena materi duabing suara yang } \\
\text { dengan dubbing } \\
\text { menjelaskan setiap langkah dan } \\
\text { tindakan langkah dan tindakan mudah } \\
\text { Setiap langka } \\
\text { untuk diikuti oleh mahasiswa } \\
\text { Setiap langkah mudah untuk diikuti }\end{array}$ \\
\hline ditinja & $\begin{array}{l}\text { Adapun penilaian ahli media } \\
\text { u dari dua indikator penilaian }\end{array}$ \\
\hline $\begin{array}{l}\text { yaitu } \\
\text { pemrc } \\
\text { tabel }\end{array}$ & $\begin{array}{l}\text { tampilan video dan } \\
\text { raman sebagaimana dalam } \\
\text { rikut: }\end{array}$ \\
\hline
\end{tabular}

Tabel 5. Penilaian tampilan video

\begin{tabular}{ll}
\hline $\begin{array}{l}\text { Aspek } \\
\text { Penilaian }\end{array}$ & Aspek yang Dinilai \\
\hline & Kapasitas video \\
& Durasi Video \\
& Kejelasan gambar pada video \\
& Tata letak tulisan dalam video \\
& Warna tulisan dalam video \\
& Pemilihan ukuran dan jenis tulisan \\
& Backsound yang mendukung video \\
& Kubbing penjelasan dari video \\
& gambar denaian penjelasan dengan
\end{tabular}


Tabel 6. Penilaian pemrograman

\begin{tabular}{ll}
\hline $\begin{array}{l}\text { Aspek } \\
\text { Penilaian }\end{array}$ & Aspek yang Dinilai \\
\hline & $\begin{array}{l}\text { Langkah-langkah materi dalam video } \\
\text { Kemudahan media untuk dipahami }\end{array}$ \\
& Ketepatan memilih model \\
& Katepatan gerakan model \\
& Kesesuaian properti yang digunakan \\
& Kesesuaian kostum yang digunakan \\
& Kedel \\
& Kualitas editing video \\
& materi \\
\cline { 3 - 3 } & Data yang disajikan berupa hasil
\end{tabular}
analisis angket dari ahli ahli materi, hal ini dilakukan untuk mengetahui hasil produk yang akan dikembangkan tidak keluar dari ilmu kebidanan dan sesuai dengan tema yang disajikan dalam mata kuliah kegawatdaruratan maternal dan neonatal.

Tabel 7. Penilaian ahli materi

\begin{tabular}{lcccc}
\hline Aspek Penilaian & Butir & $\begin{array}{l}\text { Skor } \\
\text { Perolehan }\end{array}$ & $\begin{array}{l}\text { Rata- } \\
\text { rata }\end{array}$ & Kategori \\
\hline Materi & 7 & 21 & 3.0 & Sangat \\
Pembelajaran & 7 & 20 & 2.8 & Baik \\
\hline
\end{tabular}

Dari Tabel 7 terlihat bahwa

materi dalam pengembangan media pembelajaran berbasis video masuk dalam kategori baik untuk dilanjutkan pada uji coba. Rekapitulasi hasil penelitian ahli materi jika disajikan dalam bentuk diagram sebagai berikut.

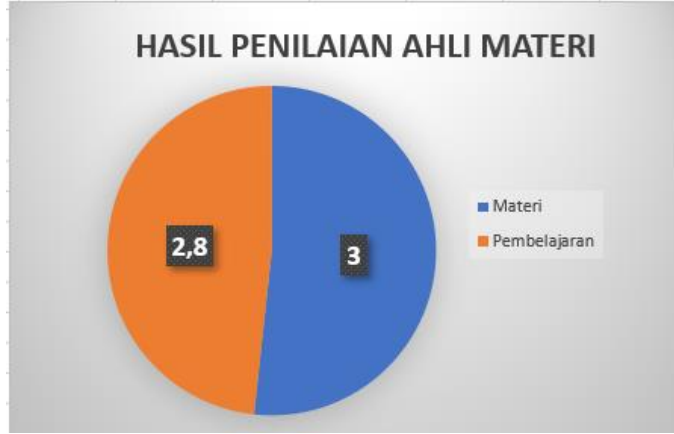

Diagram 1. Hasil penialaian ahli materi

Adapun penilaian ahli media dilakukan oleh video editor profesional selaku pakar untuk meninjau media dari aspek tampilan dan pemrograman. Hasil penilaian media pembelajaran dari segi kualitas video dapat dilihat pada tabel 8 sebagai berikut.

Tabel 8. Penilaian ahli media

\begin{tabular}{lccrl}
\hline Aspek Penilaian & Butir & $\begin{array}{l}\text { Skor } \\
\text { Perolehan }\end{array}$ & $\begin{array}{l}\text { Rata- } \\
\text { rata }\end{array}$ & Kategori \\
\hline Tampilan & 8 & 20 & 2.5 & Baik \\
Pemrograman & 8 & 25 & 3.1 & $\begin{array}{l}\text { Sangat } \\
\text { Baik }\end{array}$ \\
\hline
\end{tabular}

Dari Tabel 8 dapat dilihat bahwa media pembelajaran dari aspek tampilan masuk dalam kategori baik hal ini menunjukkan bahwa media ini layak untuk diujicobakan. Rekapitulasi hasil penelitian ahli media jika disajikan dalam bentuk diagram sebagai berikut.

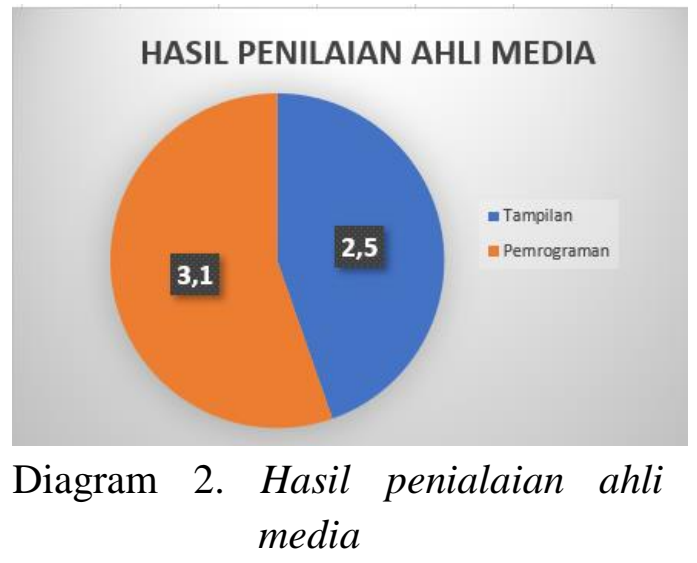


Data dari hasil validasi oleh tim ahli materi berada pada kualifikasi baik dan ahli media dengan kualifikasi sangat baik, sehingga tidak perlu dilakukan revisi. Meskipun demikian tim ahli masing-masing memberikan saran terhadap pengembangan media pembelajaran berbasis video.

Tabel 9. Perbedaan media video sebelum dan sesudah diberikan saran oleh ahli materi

\begin{tabular}{|c|c|c|}
\hline $\begin{array}{l}\text { Saran } \\
\text { Ahli Materi }\end{array}$ & Sebelum & Sesudah \\
\hline $\begin{array}{l}\text { Selain suara, } \\
\text { lebih baik jika } \\
\text { ada tulisan } \\
\text { untuk } \\
\text { menjelaskan } \\
\text { setiap ucapan } \\
\text { narator } \\
\text { Pada saat } \\
\text { memegang } \\
\text { pasien harus } \\
\text { menggunakan } \\
\text { handscoon }\end{array}$ & $\begin{array}{l}\text { Ada beberapa } \\
\text { footage model } \\
\text { tidak } \\
\text { menggunakan } \\
\text { handscoon saat } \\
\text { menyentuh } \\
\text { pasien }\end{array}$ & $\begin{array}{l}\text { Diberikan } \\
\text { subtitle untuk } \\
\text { memudahkan } \\
\text { mahasiswa } \\
\text { dalam } \\
\text { memahami } \\
\text { isi materi } \\
\text { Seluruh } \\
\text { footage saat } \\
\text { model } \\
\text { menyentuh } \\
\text { pasen } \\
\text { menggunakan } \\
\text { handscoon }\end{array}$ \\
\hline $\begin{array}{l}\text { Masukkan } \\
\text { tujuh langkah } \\
\text { memcuci } \\
\text { tangan }\end{array}$ & $\begin{array}{lr}\text { Pada } & \text { video } \\
\text { belum } & \text { ada } \\
\text { langkah } & \\
\text { mencuci tangan }\end{array}$ & $\begin{array}{l}\text { Sudah ada } \\
\text { tujuh langkah } \\
\text { mencuci } \\
\text { tangan } \\
\text { didalam } \\
\text { video }\end{array}$ \\
\hline \multicolumn{3}{|l|}{ Ahli Media } \\
\hline $\begin{array}{l}\text { Memperbaiki } \\
\text { ksesuai } \\
\text { gambar } \\
\text { dengan suara } \\
\text { narator } \\
\text { Kapasitas } \\
\text { video terlalu } \\
\text { besar }\end{array}$ & $\begin{array}{lr}\text { Ada } & \text { beberapa } \\
\text { gambar } & \text { yang } \\
\text { tidak } & \text { sesuai } \\
\text { dengan } & \text { ucapan } \\
\text { narator } & \\
\text { Kapasitas } & \text { video } \\
1 \text { GB } & \end{array}$ & $\begin{array}{l}\text { Semua } \\
\text { gambar sudah } \\
\text { sesuai dengan } \\
\text { ucapan } \\
\text { narator } \\
\text { Melakukan } \\
\text { extreme } \\
\text { compress } \\
\text { menjadi } 150 \\
\text { Mb }\end{array}$ \\
\hline $\begin{array}{l}\text { Durasi terlalu } \\
\text { panjang }\end{array}$ & $\begin{array}{l}\text { Durasi video } 25 \\
\text { menit }\end{array}$ & $\begin{array}{l}\text { Durasi video } \\
14 \text { menit }\end{array}$ \\
\hline Setelah & \multicolumn{2}{|c|}{ menerima dan } \\
\hline $\begin{array}{l}\text { memperbaiki } \\
\text { masukan dari } \\
\text { media dilak }\end{array}$ & $\begin{array}{l}\text { seluruh } \\
\text { ara ahli ma } \\
\text { an uji }\end{array}$ & $\begin{array}{l}\text { ran dan } \\
\text { ri dan ahli } \\
\text { ba pada }\end{array}$ \\
\hline
\end{tabular}

Pada kegiatan ini mahasiswa diberikan angket dimana daftar pertanyaannya dan hasil angketnya disajikan dalam tabel 10 berikut:

Tabel 10. Hasil Respon Mahasiswa terhadap media video kelompok kecil

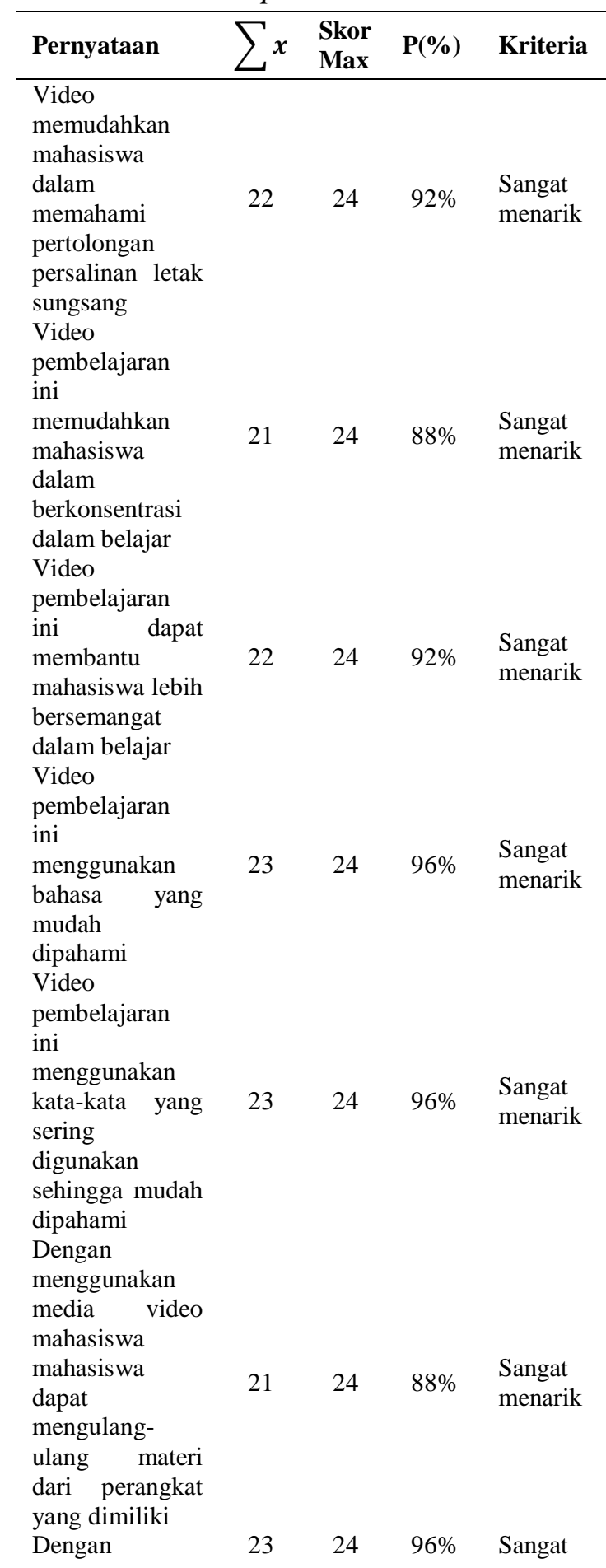




\begin{tabular}{lcccc}
\hline Pernyataan & $\sum x$ & $\begin{array}{l}\text { Skor } \\
\text { Max }\end{array}$ & $\mathbf{P}(\%)$ & Kriteria \\
\hline $\begin{array}{l}\text { pembelajaran } \\
\text { menggunakan }\end{array}$ & & & & menarik \\
media video \\
mahasiswa \\
dapat dengan \\
mudah \\
menjelaskan \\
kembali materi \\
yang diterima \\
Jumlah
\end{tabular}

Berdasarkan data kuantitatif yang ditemukan pada tabel 10 melalui uji coba kelompok kecil, maka selanjutnya adalah melakukan perhitungan persentase tingkat kemenarikan media video yang disajikan dengan menggunakn rumus:

$$
\begin{aligned}
& \mathrm{P}=\frac{\sum x}{\sum x 1} \times 100 \\
& \mathrm{P}=\frac{155}{168} \times 100 \\
& \mathrm{P}=92 \% \text { (Pembulatan) }
\end{aligned}
$$

Melihat hasil analisa perhitungan diatas maka diperoleh presentase $92 \%$. Jika angka tersebut dikonversi kedalam tabel skala maka tingkat ketercapaian $92 \%$ dengan kualifikasi sangat baik. Sebagai kesimpulan pada pengujian ini adalah video tidak perlu direvisi.

Kegiatan revisi produk yang direncanakan didalam rancangan penelitian hanya melakukan revisi pada beberapa masukan ahli materi dan ahli media, sementara untuk konten secara keseluruhan setelah melalui pengujian kelompok kecil ditemukan hasil sebesar 92\% dengan kualifikasi sangat baik atau sangat menarik.

Tahap selanjutnya selajutnya media akan diuji coba pada kelompok besar. Media video akan diujikan kepada 50 mahasiswa di kelas 2A Akademi Kebidanan Pelamonia.
Adapaun data kuantitatif yang ditemukan sebagai berikut:

Tabel 11. Hasil respon mahasiswa terhadap media video kelompok besar

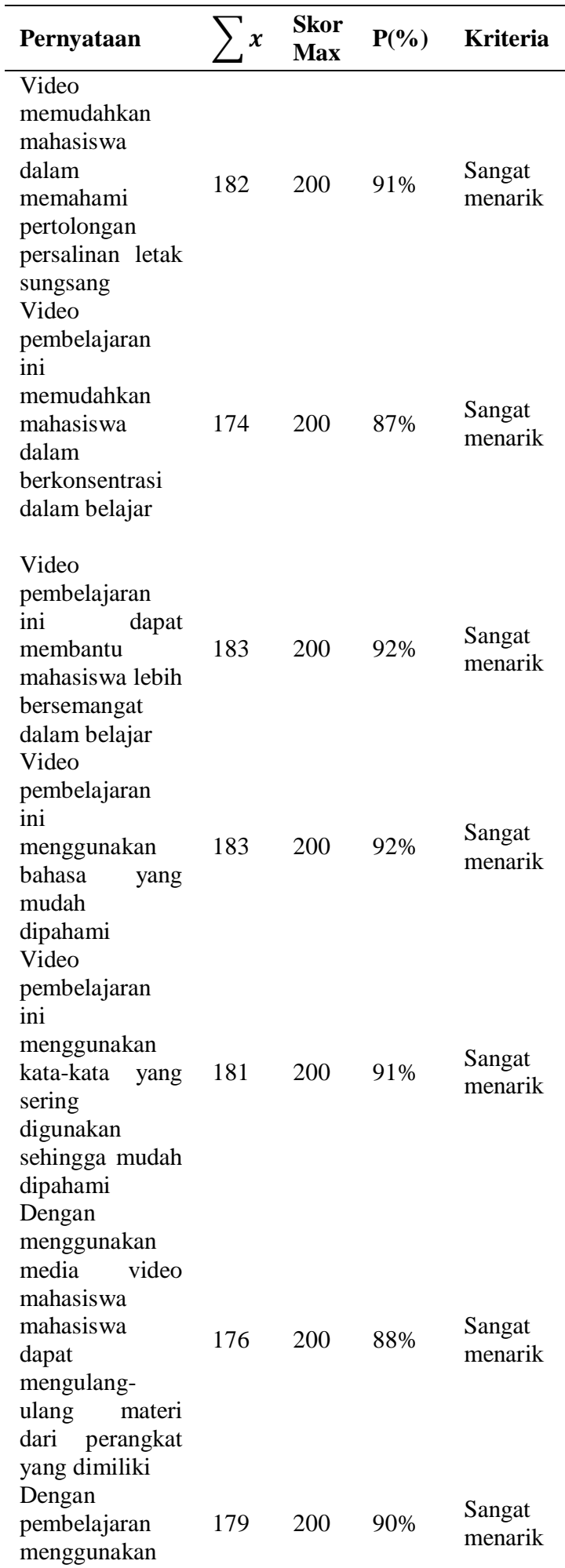




\begin{tabular}{|c|c|c|c|c|}
\hline Pernyataan & $\sum x$ & $\begin{array}{l}\text { Skor } \\
\text { Max }\end{array}$ & $\mathbf{P}(\%)$ & Kriteria \\
\hline $\begin{array}{l}\text { media video } \\
\text { mahasiswa } \\
\text { dapat dengan } \\
\text { mudah } \\
\text { menjelaskan } \\
\text { kembali materi } \\
\text { yang diterima }\end{array}$ & & & & \\
\hline Jumlah & 1258 & 1400 & $90 \%$ & $\begin{array}{l}\text { Sangat } \\
\text { menarik }\end{array}$ \\
\hline
\end{tabular}

Berdasarkan data kuantitatif

yang ditemukan pada tabel 11 melalui uji coba kelompok besar, maka selanjutnya adalah melakukan perhitungan persentase tingkat kemenarikan media video yang disajikan dengan menggunakn rumus:

$$
\begin{aligned}
& \mathrm{P}=\frac{\sum x}{\sum x 1} \times 100 \\
& \mathrm{P}=\frac{1258}{1400} \times 100 \\
& \mathrm{P}=90 \% \text { (Pembulatan) }
\end{aligned}
$$

Melihat hasil analisa perhitungan diatas maka diperoleh presentase $90 \%$. Jika angka tersebut dikonversi kedalam tabel skala maka tingkat ketercapaian $90 \%$ dengan kualifikasi sangat baik. Sebagai kesimpulan pada pengujian ini adalah video tidak perlu direvisi.

Kegiatan revisi produk yang direncanakan didalam rancangan penelitian hanya melakukan revisi pada beberapa masukan ahli materi dan ahli media, sementara untuk konten secara keseluruhan setelah melalui pengujian kelompok besar ditemukan hasil sebesar 90\% dengan kualifikasi sangat baik atau sangat menarik.

\section{c. Tahap Evaluasi}

Model final merupakan bagian dari tahap evaluasi setelah media video telah dinilai oleh ahli materi dengan menilai dua aspek yaitu isi materi dan metode pembelajaran dengan masingmasing kriteria sangat baik untuk isi materi dan baik untuk pemebelajaran. Begitu juga untuk penilaian ahli media dengan dua pokok penilaian yaitu kualitas video dan pemrograman, dengan hasil akhir setelah dikonversi kriteria baik untuk kualitas video dan sangat baik untuk pemrograman. Ditambah ada beberapa saran revisi dari masing-masing ahli. Saran tersebut telah dilaksanakan dalam bentuk perbaikan dan penambahan beberapa footage yang dibutuhkan.

Aspek utama yang dari tujuan penelitian ini adalah melihat sejauh mana media video layak digunakan sebagai penujang Pengembangan media pembelajaran pada mata kuliah kegawatdaruratan maternal dan neonatal.

Pada penelitian yang telah dilakukan, penelitian ini menghasilkan suatu informasi dalam bentuk video dinamis berupa gambar, suara, dalam teks sebagai penjelasan tambahan yang sangat membantu dalam proses transfer pengetahuan.

Menurut (Anwar, 2016) secara umum multimedia dapat diartikan sebagai kombinasi teks, gambar, suara dan video yang digabungkan menajadi satu bagian kerja yang menghasilkan informasi tidak hanya bisa dilihat dalam bentuk cetakan melainkan juga didengar dan memudahkan dalam kegiatan simulasi setelah penyajiannya.

Setelah uji coba yang panjang mulai dari pengujian kelayakan dari Ahli materi dan ahli media, pengujian juga telah dilakukan pada mahasiswa dengan sasaran utama pada dua 
kelompok. Kelompok yang dimaksud adalah kelompok kecil dan kelompok besar dari mahasiswa AKBID Pelamonia yang memprogramkan mata kuliah kegawatdaruratan maternal dan neonatal agar lebih jelas akan disajikan dalam tabel berikut:

Tabel 12. Hasil uji pada mahasiswa kelompok kecil dan kelompok besar

\begin{tabular}{lcc}
\hline $\begin{array}{l}\text { Sasaran } \\
\text { pengujian }\end{array}$ & $\mathbf{P}(\%)$ & Kriteria \\
\hline $\begin{array}{l}\text { Pengujian pada } \\
\text { kelompok kecil } \\
\text { dengan jumlah } \\
\text { mahasiswa } 6\end{array}$ & $92 \%$ & Sangat \\
orang & \\
$\begin{array}{l}\text { Pengujian pada } \\
\text { kelompok besar } \\
\text { dengan jumlah } \\
\text { mahasiswa 50 } \\
\text { orang pada } \\
\text { kelas 2A }\end{array}$ & $\begin{array}{l}\text { Sangat } \\
\text { menarik }\end{array}$ \\
\hline \multicolumn{3}{c}{ Pengembangan } \\
pembelajaran pada mata kuliah \\
kegawatdaruratan maternal dan neonatal \\
khususnya pertolongan persalinan letak \\
sungsang dengan menggunakan video \\
based learning yang mengacu pada \\
kategori multimedia interaktif layak \\
digunakan sebagai media pembelajaran \\
berdsarkan hasil uji yang telah \\
dilakukan.
\end{tabular}

\section{KESIMPULAN}

Berdasarkan data hasil penelitian dan pembahasan yang telah dijelaskan pada bab sebelumnya dapat ditarik kesimpulan sebagai berikut:

1. Tersusun media pembelajaran berbasis video pertolongan persalinan sungsang pada mata kuliah kegawatdaruratan maternal dan neonatal yang telah diuji dinilai oleh ahli materi dengan menilai dua aspek yaitu isi materi dan metode pembelajaran dengan masingmasing kriteria sangat baik untuk isi materi dan baik untuk pemebelajaran. Begitu juga untuk penilaian ahli media dengan dua pokok penilaian yaitu kualitas video dan pemrograman, dengan hasil akhir setelah dikonversi kriteria baik untuk kualitas video dan sangat baik untuk pemrograman

2. Kelayakan media pembelajaran berbasis video telah diuji melalui kelompok kecil dengan rata-rata memperoleh nilai presentase $92 \%$ denga kriteria "sangat menarik", seperti halnya pada saat pengujian di kelompok besar dengan nilai presentase $90 \%$ dengan kriteria "sangat menarik" sehingga kesimpulan dari penelitian ini adalah media video yang dikembangkan "sangat layak" untuk digunakan.

\section{DAFTAR PUSTAKA}

AH Sanaky, Hujair. (2012). Media Pembelajaran. Buku Pegangan Wajib Guru Dan Dosen. Yogyakarta: Kaukaba Dipantara.

Anwar, Efendi. (2016). Pengembangan Media Pembelajaran Berbasis Video Tutorial Pada Mata Kuliah Mekanika Tanah.

Arikunto, Suharsimi. (2016). Prosedur Penelitian: Suatu Pendekatan Praktik Jakarta: Rineka Cipta.

Astrid, Aini (2016). Pengaruh dan Pola Aktivitas Penggunaan Internet serta Media Sosial pada Siswa SMPN $52 \quad$ Surabaya. http://dx.doi.org/10.20473/jisebi $.2 .1 .17-22$. 
Daryanto. 2015. Media Pembelajaran. Bandung: Sarana Tutorial Nurani.

D. Mardapi. (2018). Teknik Penyusunan Instrumen Tes dan Nontes. Yogyakarta: Parama Publisihing.

Elianti. 2013. Pengaruh Kemampuan Mengajar Dosen Program Studi Matematika Fkip Unsyiah Terhadap Prestasi Belajar Mahasiswa Dalam Mata Kuliah Trigonometri.

Fauzan MA, Rahdiyanta D. 2017. Pengembangan Media Pembelajaran Berbasis Video pada Teori Pemesinan Frais. $J$ Din Vokasional Tek Mesin. 2017;2(2):82.

Hasthagina., \& Hellen. (2013). Pengembangan media video pembelajaran penatalaksanaan atonia uteri Jurusan Kebidanan di Politeknik Kesehatan Kementerian Kesehatan Malang.

http://repository.um.ac.id/id/epri nt/402.

Jalal, M. (2020). Kesiapan Guru Menghadapi Pembelajaran Jarak Jauh Di Masa Covid-19. SMART KIDS: Jurnal Pendidikan Islam Anak Usia Dini, 2(1), 35. https://doi.org/10.30631/smartki ds.v2i1.61.

Kristanto, Andi (2011). Pengembangan Model Media Video Pembelajaran Mata Kuliah Pengembangan Media Video/Tv Program Studi Teknologi Pendidikan Fakultas Ilmu Pendidikan Universitas Negeri Surabaya.

Marwijah, Yosef, Waspodo. (2014). Pengembangan Video Pembelajaran Praktik Pemberian Nutrisi Melalui Naso
Gastric Tube (NGT) Mata Kulaih Keterampilan Dasar Kebidanan di Diploma III Kebidanan. Kesehatan. (14):113.https://jurnal.poltekkespalem bang.ac.id/index.php/JPP/article/ view/181.

Milfayetty, dkk. (2015). Psikologi Pendidikan. Medan: PPs Unimed.

Mulyana, Deddy \& Solatun. (2013). Metode Penelitian Komunikas: contoh-contoh penelitian kualitatif dengan pendekatan praktis. Cetakan ke 3. Bandung: PT. Remaja Rosdakarya.

Munir. (2017). Pembelajaran Digital. Bandung: Penerbit Alfabeta.

Nurkancana. (2014). Evaluasi Hasil Belajar. Surabaya: Usaha Nasional.

Noveri, Hayati. (2020). Media Pembelajaran Bahasa dan Sastra Indonesia dan Teknologi Informasi. Banten: Unpam Press.

Rahmawati, Rizki dkk. Keefektifan Penerapan ELearning Quipper School Pada Pembelajaran Akuntansi di SMA Negeri 2 Surakarta. Jurnal Tata Arta.Vol. 1, No. 1, 2015.

Sadikin, A., \& Hamidah, A. (2020). Pembelajaran Daring di Tengah Wabah Covid-19. Biodik, 6(2), 109-119.

https://doi.org/10.22437/bio.v6i 2.9759.

Sugiyono. (2014). Metode Penelitian Pendidikan Pendekatan Kuantitatif, Kualitatif, dan $R \& D$. Bandung: Alfabeta.

Slameto. (2013). Belajar dan FaktorFaktor yang Mempengaruhi. Jakarta: Rineka Cipta.

Sutopo, Ariesto Hadi. (2012). Teknologi Informasi dan Komunikasi 
dalam Pendidikan. Yogyakarta: Graha Ilmu.

Syahroni, M., Dianastiti, F. E., \& Firmadani, F. (2020). Pelatihan Media Pembelajaran Berbasis Teknologi Informasi untuk Meningkatkan Keterampilan Guru dalam Pembelajaran Jarak Jauh.

Warsita, Bambang. (2011). Pendidikan Jarak Jauh. Bandung: Rosda.

Yazdi, Mohammad. (2012). E-learning Sebagai Media Pembelajaran Interaktif Berbasis Teknologi Informasi. Jurnal Ilmiah Foristek Vol. 2, No. 1, Maret 2012. 